\title{
TITLE:
}

\section{Reporls from the Field: Gombe, Tanzania : Twins Born at Mitumba}

$\operatorname{AUTHOR}(\mathrm{S}):$

Goodall, Jane

\section{CITATION:}

Goodall, Jane. Reporls from the Field: Gombe, Tanzania : Twins Born at Mitumba. Pan Africa News 1995, 2(2): 7-8

ISSUE DATE:

1995-10

URL:

http://hdl.handle.net/2433/143326

RIGHT:

Copyright (C) Pan Africa News. 


\section{Reports from the Field \\ $++++$}

\section{GOMBE, TANZANIA}

\section{TWINS BORN AT MITUMBA}

In April 1995 Rafiki, a female of Gombe's northern Mitumba community, gave birth to twins. This was only the second known multiple birth in 35 years. The first pair of known twins were born to Melissa, a high ranking female of Gombe's Kasakela Community, in 1977 and were fraternal twins. Melissa had great difficulty in caring for two infants: she never seemed to have enough milk to satisfy both and during travel one or the other of the twins, sometimes both together, would half fall and cry so that their mother had to stop to readjust their position. Some of her problems may have been due to the fact she was partially paralyzed in her neck and shoulders during the 1966 polio epidemic and though she made a remarkable recovery she was never strong. Almost from the start the one twin got weaker and it was not surprising that he died aged 10 months during an epidemic of a pneumonia-like illness. His skeletal development resembled that of a normal infant of one to two months old and behaviorally he was like an infant too. The survivor, Gimble, was not much further advanced at the time of his twin's death, though he picked up quickly once he was getting all Melissa's milk for himself.

Rafiki, in marked contrast to Melissa, was highly skilled in her handling of two babies. They are named Roots (Rootsy), a male, and Shoots (Shootsie), a female. They are not identical twins: Rootsy has a fluffy white beard on his chin while Shootsie has only a few long white hairs in her beard but unusually long, very fine white hairs on her upper lip. They are strong, active and smart. Melissa's twins always had difficulty clinging to their mother's belly. They gripped well enough but so often one would grip Mum with one hand and his twin with the other so that both fell, both whimpered and Melissa had to stop and readjust them before she could move on. When Melissa was high in the trees we were always concerned for the safety of her twins. But Roots and Shoots have no such problems, perhaps because Rafiki has shown exceptional maternal skills from the 
start. At first she would gather them both up with one hand and arm, rather like a rugby player when he runs with a ball! Now that they are older they mostly manage to stay in place on their own but their mother always warns them before she moves off. Even when she has to make a huge and sudden leap - when, for example, a socially roused male starts displaying below her tree - the two babies are usually able to remain in place without trouble.

The twins are a pure delight to watch, interested in the world around them, reaching out to touch leaves and twigs. They seem to be fascinated by each other. Sometimes, at least while I was at Gombe in June, Rootsy seemed slightly startled when on turning his head he found himself face-to-face with his sister. Three times he reacted by kissing her - on the lips. He is slightly more precocious than Shootsie. I saw him grab vigorously for some of the fruit Rafiki was eating. He once succeeded in getting a little piece of the sticky skin and spent the next 10 minutes chewing it. This means he falls exactly into the normal developmental scale for wild chimp infants: tasting first solids at 3 months.

Rafiki apparently has no shortage of milk. There is none of the continuous, desperate searching that characterized the nursing behaviour of Melissa's twins. Roots and Shoots sometimes suckle at the same time and sometimes separately, but after a bout they seem satisfied and often drop off to sleep.

We are cautiously optimistic these twins will make it. Steve Patch who is working with Gabo Toro, Tofiki Matama and Russell Amy in Mitumba will send an update for the next issue of Pan.

\section{Jane Goodall}

Ed. note: The first set of twins ever observed born to the chimpanzees of Mahale in 29 years of research were seen on 22 January 1994. Sadly, the twins did not live. Anyone who is interested in the details of this event can read about the twins in an upcoming issue of African Study Monographs (expected publication 12/95) or contact the author, Akiko Matsumoto, Dept of Zoology, Fac Science, Kyoto University, Sakyo-ku, Kyoto 606 JAPAN 